\title{
Peningkatan Kualitas Produksi Pupuk Organik P-126 Dengan Menggunakan Metode Lean Manufacturing (Studi Kasus : PT. Molindo Raya Industrial)
}

\author{
Muhammad Desryadi Ilyas dan H. Hari Supriyanto Ir,. MSIE \\ Jurusan Teknik Industri, Fakultas Teknologi Industri, Institut Teknologi Sepuluh Nopember (ITS) \\ Jl. Arief Rahman Hakim, Surabaya 60111 Indonesia \\ e-mail: hariqive@ie.its.ac.id
}

\begin{abstract}
Abstrak- PT. Molindo Raya Industrial merupakan perusahaan penghasil pupuk organik P-126 yang berlokasi di Lawang, Kabupaten Malang dengan kapasitas produksi lebih dari 10.000 ton per tahun. Untuk memenangkan persaingan di bidang produksi pupuk organik, perusahaan dituntut untuk melakukan peningkatan kualitas proses produksi secara berkelanjutan dengan mereduksi waste yang ada. Meskipun produksi pupuk organik P-126 di PT. Molindo Raya Industrial mengalami peningkatan, namun masih terdapat beberapa waste, diantaranya waiting yang disebabkan oleh breakdwon mesin produksi. Waste kedua ialah defect berupa granul yang tidak memenuhi spesfikasi diameter, material hasil cleaning dan karung finished good yang sobek dan waste ketiga ialah over production. Untuk mengatasi permasalahan tersebut dilakukan perbaikan dengan menggunakan metode lean manufacturing. Pada penelitian ini menggunakan framework DMIC six sigma, tahapan pertama ialah tahap define untuk mengidentifikasi permasalahan dengan menggunakan tools Big Picture Mapping, Activity Classification dan identifikasi waste berdasarkan E-DOWNTIME. Tahapan kedua ialah measure yang digunakan untuk mengukur kerugian perusahaan yang diakibatkan adanya waste. Selanjutnya adalah tahap analyze menggunakan tools 5 Why's dan FMEA untuk mengetahui root cause adanya waste, kemudian tahap terakhir ialah tahap improvement, pada tahap improvement dilakukan penyusunan dan pemilihan alternatif usulan perbaikan dengan mengunakan value engineering. Usulan perbaikan terpilih dalam upaya meningkatkan proses produksi pupuk organik P-126 dengan value tertinggi diantaranya mengevaluasi penjadwalan preventif maintenance mesin produksi, menyusun penjadwalan mesin produksi yang kritis, evaluasi SOP dan penerapan SOP, melaksanakan pelatihan untuk operator dan karyawan dan perbaikan sistem demand forecasting.
\end{abstract}

Kata Kunci-5 Why's, BPM Mapping, E-DOWNTIME, FMEA, Lean Manufacturing.

\section{PENDAHULUAN}

$\mathrm{P}^{\mathrm{T}}$ T. Molindo Raya Industrial merupakan salah satu perusahaan penghasil pupuk organik dengan kapasitas produksi lebih dari 10.000 ton per tahun yang mengelola limbah organik menjadi pupuk organik P-126, perusahaan yang berlokasi di Lawang, Kabupaten Malang ini telah berdiri sejak tahun 1973. Realisasi dan target produksi pupuk organik P-126 pada gambar 1. Meskipun produksi pupuk organik P-126 di PT. Molindo Raya Industrial mengalami peningkatan, namun masih terdapat beberapa waste yang menurut Vincent Gazpert (2007) merupakan sesuatu yang dapat merugikan perusahaan. Waste pada proses produksi pupuk organik P-126 diantaranya, terdapatnya defect pada produk, waiting yang disebabkan oleh breakdown mesin produksi yang menyebabkan proses produksi terhenti dan over production produk yang melebihi dari target produksi yang telah ditentukan di awal.

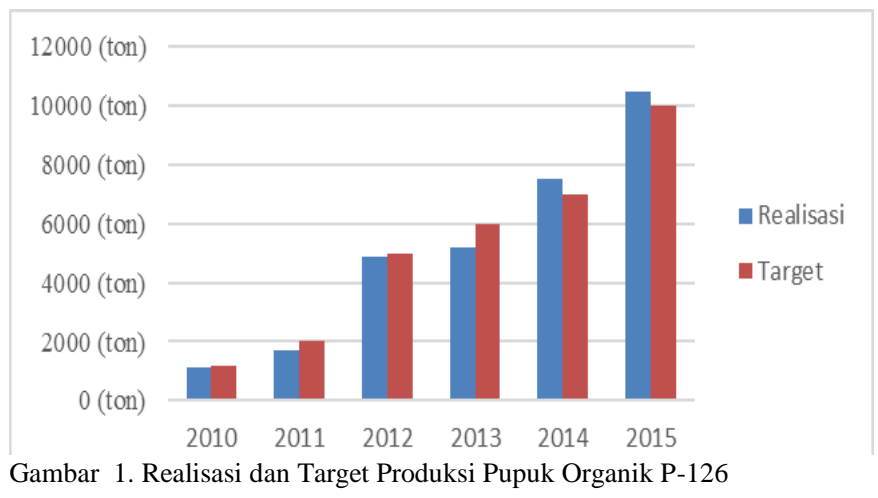

Adanya beberapa waste pada proses produksi pupuk organik P-126 mengindikasikan adanya permasalahan, sehingga pada tugas akhir ini akan dilakukan penelitan mengenai penyelesaian beberapa masalah perusahaan yang telah dideskripsikan di atas. Untuk meyelesaikan permasalahan tersebut digunakan konsep lean manufacturing yang bertujuan untuk mengidentifikasi dan mengeliminasi non value added activity serta meningkatkan kualitas dalam langkah perbaikan suatu proses (Hu, et al., 2008). Selain itu lean manufacturing merupakan metode untuk memaksimalkan nilai dari suatu proses melalui peningkatan kualitas secara berkelanjutan untuk meminimasi waste yang didapatkan dengan mengelompokkan aktivitas ke dalam aktivitas yang memiliki nilai tambah dan aktivitas yang tidak memiliki nilai tambah (Sundar, et al.,2014). Sehingga dengan penerapan metode lean manufacturing, akan meningkatkan kualitas proses produksi pupuk organik P-126 dari PT. Molindo Raya Industrial. 


\section{METODOLOGI PENELITIAN}

Alur penelitian yang digunakan pada penelitian digambarkan pada flowchart di bawah ini:

Tahap Identifikasi

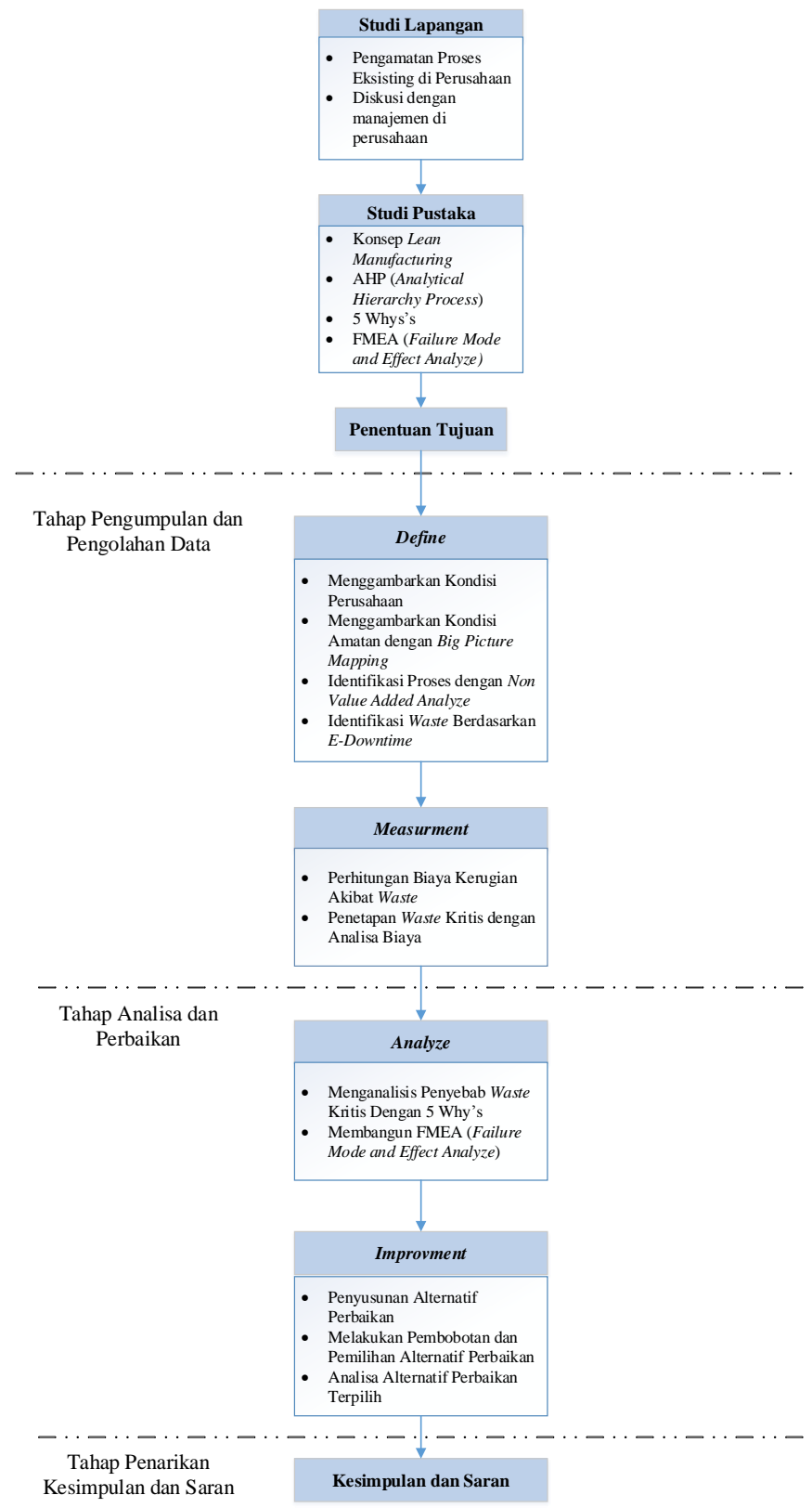

Gambar 2. Flowchart Penelitian

\section{PENGUMPULAN DAN PENGOLAHAN DATA}

\section{A. FASE DEFINE}

\section{1) Pendefinisian Objek Amatan}

Pabrik pupuk organik P-126 PT. Molindo Raya Industrial terdiri dari beberapa stasiun kerja, diantaranya stasiun penyimpanan untuk penghancuran raw material yang menggumpal dan penyimpanan sementara, stasiun penghalusan untuk menghaluskan raw material hingga berbentuk curah, stasiun pembentukan granul, stasiun pemanasan untuk mengeraskan granul yang telah terbentuk, stasiun pendinginan, stasiun penyaringan untuk memilah granul sesuai spesifikasi produk yang ditentukan, dan stasiun pengemasan. Berikut merupakan tabel stasiun kerja di pabrik pupuk oragnik P-126.

Tabel 1

Stasiun Kerja Pabrik Pupuk Organik P-126

\begin{tabular}{ccccc}
\hline \hline No & Stasiun Kerja & Mesin & $\begin{array}{c}\text { Jumlah } \\
\text { Mesin }\end{array}$ & $\begin{array}{c}\text { Jumlah } \\
\text { Operator }\end{array}$ \\
\hline 1 & Penyimpanan & Hopper & 1 & 1 \\
2 & Penghalusan & Crusher & 1 & 2 \\
3 & Pembentukan & Pan & 4 & 4 \\
4 & Granul & Granulator & & 1 \\
& Demanasan & Furnace & 1 & 1 \\
5 & Pendinginan & Cooler & 1 & 1 \\
6 & Penyaringan & Vibration & 1 & 1 \\
7 & Pengemasan & Timbangan & 1 & 2 \\
& & Penjahit & 1 & \\
\hline \hline
\end{tabular}

2) Big Picture Mapping

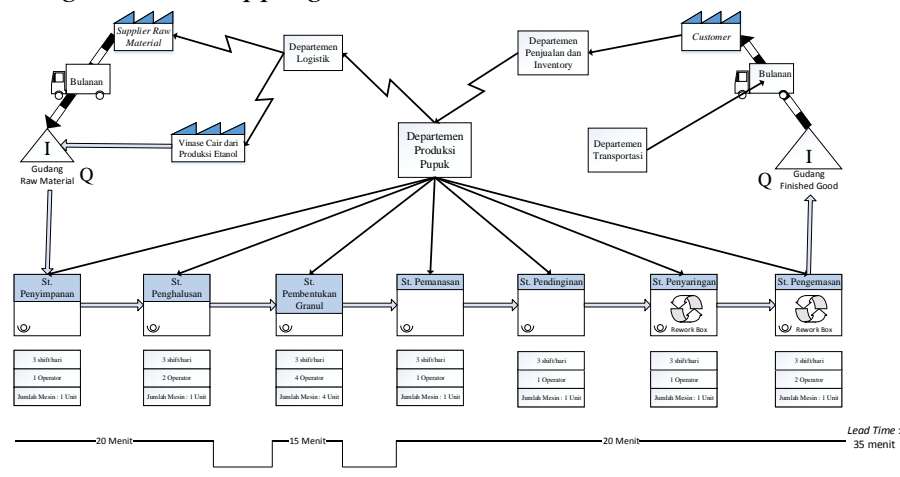

Gambar 3. Big Picture Mapping

\section{3) Waste Identification}

a) EHS (Environment, Health, and Safety)

EHS (Environment, Health, and Safety) merupakan waste yang disebabkan karena kelalaian perusahaan dalam menerapkan prinsip-prinsip $\mathrm{K} 3$, waste EHS berhubungan dengan dampak lingkungan kerja terhadap keamanan dan kesehatan operator maupun lingkungan sekitar perusahaan. Lingkungan kerja pada pabrik pupuk organik P-126 di PT. Molindo Raya Industrial memiliki tingkat pencemaran udara yang berpotensi menyebabkan kesehatan operator terganggu, hal ini disebabkan karena banyaknya debu yang berterbangan, debu tersebut merupakan raw material dari pupuk organik P-126 yang bebentuk curah. Selain hal tersebut, temperatur yang tinggi pada lingkungan pabrik berpotensi mempengaruhi kinerja dan keselamatan operator karena dengan temperatur ruangan yang tinggi dapat membuat konsentrasi operator menurun dan sewaktu temperatur udara tinggi tertutama di stasiun pemanasan, 
terkadang operator meninggalkan stasiun kerja atau membuka helm APD untuk sementara waktu guna mencari udara yang lebih segar.

\section{b) Defect}

Defect merupakan waste yang diakibatkan adanya produk cacat, rusak atau tidak berfungsi secara normal sehingga membutuhkan proses tambahan (excessive processing) ataupun proses pengerjaan kembali (rework). Defect pada pupuk organik P-126 dibedakan menjadi tiga jenis. Defect jenis pertama ialah granul yang memiliki diameter diluar spesifikasi yang telah ditentukan dan tidak dapat melewati 2 screen, hal ini berarti granul yang berdiameter di luar 1,5 mm-5 mm. Defect jenis kedua ialah material yang tidak diproses secara sempurna pada mesinmesin produksi dan didapatkan setelah proses cleaning setiap harinya. Dan defect jenis ketiga ialah karung finished good yang sobek, hal ini diakibatkan terjadi gesekan pada saat handling finished good dengan forklift maupun terjadinya gesekan antara palet dan karung sewaktu proses penataan dan penyimpanan di gudang. Berikut merupakan data defect dari pupuk organik P-126 selama tahun 2015.

Ketiga jenis defect tersebut nantinya tidak akan dibuang begitu saja melainkan akan dilakukan proses rework untuk diolah menjadi finished good yang sesuai dengan standar yang telah ditentukan. Defect jenis pertama ialah granul yang memiliki diameter diluar batas $1,5 \mathrm{~mm}-5 \mathrm{~mm}$ dan defect jenis kedua ialah material yang tidak diproses secara sempurna pada mesin-mesin produksi dan didapatkan setelah proses cleaning akan dibawa ke stasiun penyimpanan untuk dilakukan rework, rework dilakukan dengan memasukkan granul dan material ke mesin hopper di stasiun penyimpanan. Sedangkan defect jenis ketiga berupa karung sobek akan dibawa ke stasiun pengemasan untuk dilakukan rework, rework dilakukan dengan memasukkan material granul ke silo yang berada stasiun pengemasan yang kemudian akan dilakukan pengemasan dengan karung yang baru.

\section{c) Over Production}

Over production merupakan waste yang terjadi karena produksi yang berlebihan dari demand sehingga menyebabkan material, cost, dan waktu yang terbuang karena produk yang telah diproduksi tidak dapat terjual ke pasar. Pada awal tahun 2014 target produksi pupuk organik P-126 PT. Molindo Raya Industrial sebesar 7000 ton dan di akhir tahun 2014 realisasi produksi menngkat menjadi 7.500 ton. Hal ini terjadi karena permintaan dari departemen penjualan dan inventory yang memprediksi peningkatan demand pada bulan september-desember sekitar 500 ton atau 12.500 karung. Dan setelah akhir 2014 tersisa 44 ton atau 1.100 karung yang tidak terdistribusikan ke customer dan menumpuk di gudang finished good. Produk sejumlah 1.100 karung yang tidak terjual ke customer selanjutnya akan dibawa ke stasiun penyimpanan untuk dilakukan pengolahan kembali.

\section{d) Waiting}

Waiting merupakan waste yang terjadi karena adanya proses menunggu yang biasanya disebabkan oleh bottlenack pada sistem produksi atau terjadinya breakdown mesin. Pada proses produksi pupuk organik P126 di PT. Molindo Raya Industrial waste waiting sering terjadi yang disebabkan oleh adanya breakdown pada mesin. Dengan adanya breakdown pada mesin produksi akan menyebabkan kerugian pada perusahaan karena menghilangkan kesempatan produksi dari finished good, membuat operator menganggur, dan mengeluarkan biaya untuk penggantian sparepart mesin. Berikut merupakan data breakdown mesin pada tahun 2015.

Tabel 2

Data Breakdown Setiap Mesin Produksi

\begin{tabular}{lc}
\multicolumn{2}{c}{ Data Breakdown Setiap Mesin Produksi } \\
\hline \hline Mesin & $\begin{array}{c}\text { Waktu Breakdown } \\
(\mathrm{Jam})\end{array}$ \\
\hline Hopper & 24 \\
Crusher & 127 \\
Pan Granulator & 48 \\
Dryer & 154 \\
Cooler & 40 \\
Vibration Screen & 32 \\
Packaging & 16 \\
\hline \multicolumn{2}{c}{ Total } \\
\hline \hline
\end{tabular}

e) Not Utilizing Employee

Waste not utilizing employee terjadi karena penggunaan sumber daya manusia yang tidak sesuai dengan kompetensinya baik itu hardskill maupun softskill. Operator dan karyawan di pabrik pupuk organik P-126 PT. Molindo Raya Industrial sebelum memasuki dunia kerja di perusahaan, akan dilakukan pelatihan sesuai dengan kebutuhan oleh departemen personalia. Pelatihan untuk karyawan dilakukan selama 1-2 bulan sedangkan pelatihan operator dilakukan 1-2 minggu. Dengan pelatihan tersebut, kompentensi operator dan karyawan dapat dimanfaatkan perusahaan secara optimal.

\section{f) Transportation}

Waste transportation merupakan pemborosan yang terjadi pada proses transportasi material antar stasiun kerja ataupun transportasi finished good ke warehouse. Pada proses produksi pupuk organik P-126 di PT. Molindo Raya Industrial transportasi antar stasiun menggunakan material handling belt conveyor dengan ukuran yang berbeda antar stasiun. Waste transportation pada proses produksi pupuk organik P-126 tidak dapat ditemukan sehingga tidak dilakukan perhitungan waste transportation pada tahap measure. Hal ini dikarenakan aliran material baik berupa raw material maupun finished good sudah berjalan dengan efektif dan efisien. 


\section{g) Inventory}

Permasalahan inventory di pabrik pupuk oganik P-126 ialah terjadi penumpukan material work in process di mesin hopper, meskipun demikian, hal ini tidak menjadi permasalahan dari perusahaan dikarenakan mesin hopper masih dapat menampung raw material yang berada di stasiun penyimpanan yang disesuaikan dengan rencana produksi. Sehingga tidak dilakukan perhitungan untuk waste inventory pada fase measure.

\section{h) Motion}

Waste motion pada proses produksi pupuk organik P126 ditemukan pada operator yang meninggalkan stasiun kerjanya sewaktu proses produksi sedang berjalan. Meskipun demikian, waste motion ini tidak memiliki dampak yang signifikan terhadap proses produksi dan tidak mengakibatkan pengeluaran biaya oleh perusahaan. Sehingga tidak dilakukan perhitungan untuk waste motion pada fase measure

\section{i) Excessive Processing}

Waste excessive processing pada proses produksi pupuk organik P-126 dapat ditemukan pada proses pengisian granul ke dalam karung, proses tersebut berulang ketika pada proses pengisian pertama berat karung tidak mencapai $41 \mathrm{~kg}$ sehingga dilakukan pengisian granul kembali. Setelah dilakukan pengamatan, proses pengulangan pengisian granul sangat jarang terjadi dan prosesnya pun berlangsung singkat, hal dikarenakan pengalaman opertor yang dapat memperkirakan berat ketika proses memasukkan granul ke dalam karung. Oleh karena itu, waste excessive processing tidak memberi dampak yang signifikan ke proses produksi dan tidak dilakukan proses perhitungan kerugian perusahaan.

\section{B. MEASURE}

\section{1) Waste Measurment}

\section{a) Defect}

Pada tahap measure defect, dilakukan perhitungan kerugian perusahaan yang diakibatkan oleh adanya defect, kerugian perusahaan didapatkan dari mengalikan banyaknya granul yang tidak memiliki diameter sesuai spesifikasi dengan harga pokok produksi tanpa biaya material, mengalikan jumlah material hasil cleaning dengan harga pokok produksi tanpa biaya material, dan jumlah defect dalam bentuk karung sobek dengan harga. Berikut merupakan tabel Opportunity Lost Untuk Defect.

$$
\text { Tabel } 3
$$

Opportunity Lost Waste Defect

\begin{tabular}{cccr}
\hline \hline Jenis Defect & Jumlah & Satuan & Opportunity Lost \\
\hline Diameter granul tidak & 525 & ton & 315.000 .000 \\
sesuai spesifikasi & & & \\
Material hasil cleaning & 210 & ton & 126.000 .000 \\
Karung sobek & 788 & karung & 1.576 .000 \\
& 31,52 & ton & 18.912 .000 \\
\hline Total & & & 461.488 .000 \\
\hline
\end{tabular}

\section{b) Over Production}

Perhitungan opportunity lost atau biaya kerugian yang dialami perusahaan dikarenakan adanya waste over production. Opportunity lost didapatkan dari mengalikan material over production dengan dengan harga pokok produksi tanpa biaya material dan harga karung. Tabel 4 menjelakan opportunity lost untuk over production.

Tabel 4

Opportunity Lost Waste Over Production

\begin{tabular}{lcc}
\hline \hline \multicolumn{1}{c}{ Komponen Biaya } & Jumlah & Opportunity \\
& Produk & \multicolumn{1}{c}{ Lost } \\
\hline HPP (tanpa biaya material) & 44 ton & 26.400 .000 \\
Harga karung & 1.100 karung & 2.200 .000 \\
\hline \multicolumn{2}{r}{ Jumlah } & \\
\hline \hline
\end{tabular}

c) Waiting

Perhitungan opportunity lost atau biaya kerugian yang dialami perusahaan dikarenakan adanya waste waiting dengan memperhatikan beberapa komponen biaya diantaranya biaya tenaga kerja yang menganggur selama terjadinya breakdown mesin, pendapatan yang diperoleh perusahaan ketika tidak terjadi breakdown dan biaya pembelian sparepart untuk maintenance mesin produksi yang terjadi breakdown.

Tabel 5

Opportunity Lost Waste Waiting

\begin{tabular}{lr}
\hline \multicolumn{1}{c}{ Komponen Biaya } & Opportunity $\operatorname{Cost}(\mathrm{Rp})$ \\
\hline Biaya tenaga kerja & 68.922 .000 \\
Kerugian akibat HPP & \\
Biaya sparepart & 20.000 .000 \\
\hline \multicolumn{1}{c}{ Jumlah } & 567.218 .000 \\
\hline \hline
\end{tabular}

Dari data pada table 2 kemudian dilakukan pembuatan pareto chart dengan bantuan software Minitab 16 yang digunakan untuk melihat berapa kontribusi setiap mesin terhadap total waktu breakdown mesin produksi.

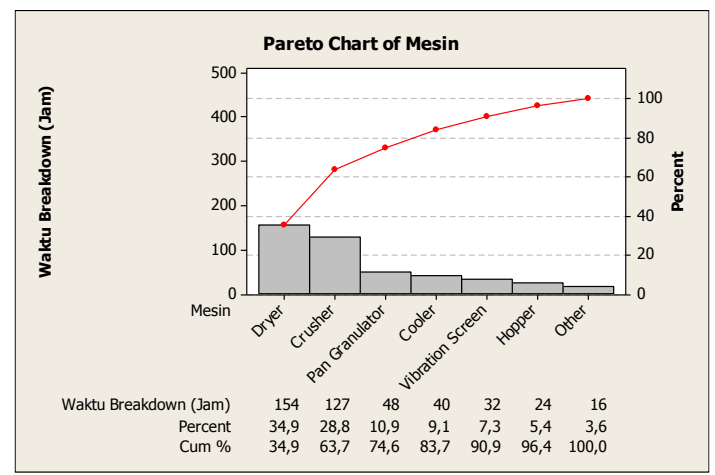

Gambar 4. Pareto Chart Mesin Produksi

Berdasarkan konsep 80-20 dari pareto chart, mesin dryer, crusher dan pan granulator memiliki pengaruh $80 \%$ dari total waktu breakdown pada proses produksi pupuk organik P-126, sehingga ketiga mesin tersebut yang 
selanjutnya akan menjadi fokusan pada tahap analyze dan improve

\section{2) Penentuan Waste Kritis}

. Penentuan waste kritis dilakukan dengan melihat kerugian financial yang dialami perusahaan atau jumlah biaya yang harus ditanggung perusahaan dengan adanya waste. Berdasarkan perhitungan biaya dari dampak yang ditimbulkan setiap waste pada sub bab waste measurment. Berikut merupakan waste yang menyebabkan perusahaan melakukan pengeluran per tahun pada proses produksi pupuk orgaik P-126.

Tabel 6

Biaya Kerugian Waste Kritis

\begin{tabular}{cr}
\hline \hline Waste & Opportunity Lost (Rp) \\
\hline Waiting & 567.218 .000 \\
Defect & 461.488 .000 \\
Over & 28.600 .000 \\
Production & \\
\hline Jumlah & 1.038 .394 .000 \\
\hline \hline
\end{tabular}

Waste waiting, defect dan over production merupaka waste yang berdampak menyebabkan pengeluran perusahaan, sehingga ketiga waste tersebut digolongkan menjadi waste kritis pada penelitian ini dan akan menjadi input untuk tahap analisa penyebab waste dan penyusunan rencana improvement.

\section{ANALISA DAN INTERPRETASI DATA}

\section{A. FASE ANALYZE}

Pada tahap analyze akan dilakukan analisa untuk mendapatkan penyebab waste kritis dengan menggunakan metode 5 Why's setiap waste dan metode FMEA (Failure Mode And Effect Analyze) untuk mengklasifikasikan resiko kegagalan dengan menggunakan nilai Risk Priority Number (RPN). Nilai RPN didapatkan dari hasil kali severity, occurrence, dan detection untuk masing root cause. Pada penelitian ini, 3 nilai RPN tertinggi akan menjadi fokusan perbaikan pada tahap improve.

Didapatkan root cause diantaranya, kurangnya kontrol dari operator saat mesin dijalankan, kualitas selang yang buruk, kurangnya maintenance burner dari dryer, tidak melakukan penggantian bucket secara berkala, kurangnya maintenance bagian blade, tidak melakukan penggantian bagian screen secara berkala, kurangnya maintenance motor, proses cleaning tidak berjalan dengan baik, kualitas belt yang buruk dan tidak melakukan penggantian bagian belt secara berkala untuk waste waiting. Operator tidak memiliki standar waktu proses pembentukan granul dan hanya dengan inspeksi fisik dan visual, kesalahan dalam forecasting demand dan operator tidak mengoprasikan mesin dengan baik untuk waste defect. Kesalahan dalam forecasting demand oleh departemen penjualan dan inventory untuk waste over production.

\section{B. FASE IMPROVE}

\section{1) Usulan Alternatif Perbaikan}

Penyusunan alternatif perbaikan dilakukan untuk usaha improvement pada root cause dengan 3 nilai RPN tertinggi setiap jenis waste. Berikut merupakan usulan alternatif perbaikan pada proses produksi pupuk organik P-126.

Tabel 7

Usulan Alternatif Perbaikan

\begin{tabular}{|c|c|c|}
\hline Alternatif & Perbaikan & Keterangan \\
\hline 1 & $\begin{array}{c}\text { Perbaikan } \\
\text { Prosedur Kerja } \\
\text { dan Pelatihan }\end{array}$ & $\begin{array}{l}\text { Melakukan evaluasi SOP dan } \\
\text { penerapannya } \\
\text { Melaksanakan pelatihan untuk } \\
\text { operator }\end{array}$ \\
\hline 2 & $\begin{array}{l}\text { Penjadwalan } \\
\text { Maintenance } \\
\text { Mesin }\end{array}$ & $\begin{array}{l}\text { Mengevaluasi penjadwalan } \\
\text { preventif maintenance mesin } \\
\text { produksi } \\
\text { Menyusun penjadwalan } \\
\text { komponen mesin produksi yang } \\
\text { kritis }\end{array}$ \\
\hline 3 & $\begin{array}{l}\text { Perbaiakan } \\
\text { sistem demand } \\
\text { forecasting }\end{array}$ & $\begin{array}{l}\text { Melakukan perbaikan sistem } \\
\text { demand forecasting dengan } \\
\text { kolaborasi dengan retailer }\end{array}$ \\
\hline
\end{tabular}

2) Kriteria Performansi Alternatif Perbaikan

Kriteria performansi didapatkan dari kolom recommended action setiap root cause yang menjadi target perbaikan sehingga didapatkan tiga jenis kriteria yang digunakan pada pemilihan usulan perbaikan diantaranya : reduksi downtime, reduksi defect dan reduksi over production. Setelah didapatkan kriteria performansi, selanjutnya dilakukan pembobotan dari ketiga jenis kriteria tersebut dengan menggunakan metode AHP dan bantuan software Expert Choice 11 untuk mendapatkan urutan prioritas berdasarkan sudut pandang expert perusahaan. Berikut merupakan rekap pembobotan performansi kriteria improvement.

Tabel 8

Rekap Bobot Kriteria Performansi Perbaikan

\begin{tabular}{clr}
\hline \hline No & \multicolumn{1}{c}{ Kriteria } & \multicolumn{1}{c}{ Bobot } \\
1 & Reduksi downtime & 0,466 \\
2 & Reduksi defect & 0,433 \\
3 & Reduksi over production & 0,1 \\
\hline \hline
\end{tabular}

\section{3) Pemilihan Alternatif Perbaikan}

Pemilihan alternatif perbaikan dilakukan dengan metode value management, konsep value management dilakukan dengan melihat value yang dihasilkan dari perbandingan performansi dan biaya untuk setiap alternatif usulan perbaikan. Pemilihan usulan alternatif perbaikan terpilih dengan melihat value tertinggi diantara kombinasi usulan alternatif perbaikan. Berikut merupakan tabel value untuk masing-masing kombinasi alternatif perbaikan. 
Tabel 9

Value Untuk Masing-Masing Kombinasi Altenatif

\begin{tabular}{|c|c|c|c|c|c|c|}
\hline \multirow{2}{*}{$\begin{array}{c}\text { Kombinasi } \\
\text { Improvement }\end{array}$} & \multicolumn{2}{|c|}{ Krite ria Performansi } & \multirow{2}{*}{ Performansi } & \multirow{2}{*}{ Cost $(\mathbf{R p )}$} & \multirow{2}{*}{ Value } \\
\cline { 2 - 4 } & $\mathbf{A}$ & $\mathbf{B}$ & $\mathbf{C}$ & & & \\
\hline & $\mathbf{0 , 4 6 6}$ & $\mathbf{0 , 4 3 3}$ & $\mathbf{0 , 1}$ & $\mathbf{9 4 4 8 7 9 5 3 , 9 4}$ & & \\
\hline 0 & 6 & 7 & 6 & 6,427 & 607.274 .080 & 1,000 \\
\hline 1 & 9 & 6 & 7 & 7,492 & 608.274 .080 & 1,164 \\
\hline 2 & 8 & 9 & 7 & 8,325 & 637.674 .080 & 1,234 \\
\hline 3 & 7 & 7 & 9 & 7,193 & 617.274 .080 & 1,101 \\
\hline 1,2 & 9 & 8 & 7 & 8,358 & 638.674 .080 & 1,237 \\
\hline 1,3 & 9 & 6 & 8 & 7,592 & 618.274 .080 & 1,160 \\
\hline 2,3 & 7 & 8 & 9 & 7,626 & 637.674 .080 & 1,130 \\
\hline $1,2,3$ & 9 & 9 & 9 & 8,991 & 638.674 .080 & 1,330 \\
\hline
\end{tabular}

Berdasarkan table 9, dapat dilihat bahwa usulan alternatif perbaikan terpilih yaitu kombinasi alternatif 1,2 dan 3 dengan value sebesar 1,330. Kombinasi alternatif 1 , 2 dan 3 yaitu, mengevaluasi penjadwalan preventif maintenance mesin produksi, menyusun penjadwalan mesin produksi yang kritis, evaluasi SOP, evaluasi penerapan SOP, melaksanakan pelatihan untuk operator dan karyawan, serta perbaikan sistem demand forecasting.

4) Analisa Usulan Perbaikan Terpilih

Analisa usulan perbaikan terpilih didasarkan pada penilian expert perusahaan terhadap usulan alternatif terpilih, dimana data dipeorleh dari kuisioner yang telah dilakukan pada tahap penentuan bobot kriteria performansi. Berikut merupakan tabel peningkatan performansi alternatif perbaikan terpilih.

Tabel 10

Persentasi Perbaikan Usulan Perbaiakan Terpilih

\begin{tabular}{cccc}
\hline Alternatif & \multicolumn{3}{c}{ Kriteria Performansi } \\
\cline { 2 - 4 } & $\mathrm{A}$ & $\mathrm{B}$ & $\mathrm{C}$ \\
\hline 0 & $60 \%$ & $70 \%$ & $60 \%$ \\
$1,2,3$ & $90 \%$ & $90 \%$ & $90 \%$ \\
Kenaikan & $30 \%$ & $20 \%$ & $30 \%$ \\
Perbaikan & $50 \%$ & $29 \%$ & $50 \%$ \\
\hline \hline
\end{tabular}

Berdasarkan tabel 10 diketahui bahwa terjadunya perbaikan performansi proses produksi pupuk organik P126, waktu downtime yang diakibatkan oleh breakdown mesin produksi akan menurun sebesar 50\%, banyaknya produk defect akan menurun sebesar $29 \%$ dari kondisi saat ini dan over production finished good akan menurun sebesar $50 \%$.

\section{KESIMPULAN}

Kesimpulan yang dapat diambil pada penelitian tugas akhir ini diantaranya : waste yang menjadi permasalahan dan menyebabkan kerugian perusahaan diantaranya waiting yang disebabkan oleh breakdwon mesin-mesin produksi dan menyebabkan kerugian sebesar Rp. 567.218.000 per tahun. Waste kedua ialah defect berupa granul yang tidak memenuhi spesfikasi diameter, material hasil cleaning dan karung finished good yang sobek dan menyebabkan kerugian sebesar Rp. 461.488.000 per tahun dan waste ketiga ialah over production dan menyebabkan kerugian Rp. 28.600.000 per tahun.

Akar permasalahan yang menyebabkan terjadinya waste pada proses produksi pupuk organik P-126 diantaranya kurangnya kontrol dari operator saat mesin dijalankan, kualitas selang yang buruk, kurangnya maintenance burner dari dryer, tidak melakukan penggantian bucket secara berkala, kurangnya maintenance bagian blade, tidak melakukan penggantian bagian screen secara berkala, kurangnya maintenance motor, proses cleaning tidak berjalan dengan baik, kualitas belt yang buruk dan tidak melakukan penggantian bagian belt secara berkala untuk waste waiting. Operator tidak memiliki standar waktu proses pembentukan granul dan hanya dengan inspeksi fisik dan visual, kesalahan dalam forecasting demand dan operator tidak mengoprasikan mesin dengan baik untuk waste defect. Kesalahan dalam forecasting demand oleh departemen penjualan dan inventory untuk waste over production.

Usulan perbaikan dalam upaya meningkatkan proses produksi pupuk organik P-126 diantaranya mengevaluasi penjadwalan preventif maintenance mesin produksi, menyusun penjadwalan mesin produksi yang kritis, evaluasi SOP dan penerapan SOP, melaksanakan pelatihan untuk operator dan karyawan dan perbaikan sistem demand forecasting.

\section{DAFTAR PUSTAKA}

[1] Agus. (2016). Daftar Gaji UMR JatimTahun 2016. Diambil kembali dari Gaji UMR.com: http://www.gajiumr.com/gaji-umrjawa-timur/

[2] Agus. (2016). Daftar Gaji UMR JatimTahun 2016. Diambil kembali dari Gaji UMR.com: http://www.gajiumr.com/gaji-umrjawa-timur/

[3] Anvari, A., Ismail, Y., \& Hojjati, S. M. (2011). A Study on Total Quality Management and Lean Manufacturing : Throught Lean Thinking Approuch. World Applied Sciences Journal.

[4] APPI. (2016). Supply and Demand 2007-2015. Asosiasi Produsen Pupuk Indonesia.

[5] BPS. (2015). bps.go.id. Dipetik Maret 11, 2016, dari https://www.bps.go.id/linkTabelStatis/view/id/971

[6] Chrysler Corporation, Ford Motor Company, General Motor Corporation. (1995). Potential Failure Mode And Effect Analysis Reference Manual.

[7] Daftar Perusahaan Karung Plastik. (2016). Diambil kembali dari Indo Tranding: http://www.indotrading.com/showcase/karungplastik

[8] Dhillon, B. S. (2006). Maintainability, Maintenance, and Realibilty For Engineers. CRC Press.

[9] Hines, P., \& Taylor, D. (2000). Going Lean. Cardiff: Lean Enterprise Research Center Cardiff Bussiness School.

[10] Hu, G., Wang, L., Fetch, S., \& Bidanda, B. (2008). A Multi Objective Model for Project Portfolio Selection to Implement Lean and Six Sigma Concepts. International Journal of Production Research.

[11] Indonesia, P. M. (2014). Indonesia Paten No. Nomor 31 Tahun 2014.

[12] Lewis, E. E. (1987). Introduction to Realibility Engineering. John Wiley \& Sons Inc.

[13] Pertanian, K. (2015). Rencana Strategis Kementerian Pertanian Tahun 2015-2019. Jakarta.

[14] Pratama, A. N. (2014). Perancangan Aktivitas Pemeliharaan dan Realibility Centered Maintenance II. Surabaya. 
[15] Pujawan, I. N. (2010). Supply Chain Management Edisi Kedua. Penerbit Guna Widya.

[16] Pyzdek, T. (2003). The Six Sigma Handbook. McGraw-Hill.

[17] Saaty, T. L. (2008). Decision Making With Analytic Hierarchy Process. International Service Science, 83.

[18] Sondalini, M. (t.thn.). Understanding How to Use The 5-Whys for Root Cause Analysis.

[19] Sundar, R., Balaji, A., \& Satheesh Kumath, R. (2014). A Review of Lean Manufacturing Implementation Techniques.

[20] Supriyanto, H. H. (2014). Penerapan Lean Six Sigma Concept Untuk Perbaikan Lini Produksi. IENACO.

[21] Womack, J. P., Jones, D. T., \& Ross, D. (2007). The Machine That Changed the World: The Story of Lean Production-Toyota's Secret Weapon in the Global Car Wars That Is Now Revolutionizing World Industry. Free Press. 